\title{
Effect of Severe Plastic Deformation Realized by Hydrostatic Extrusion on Heat Transfer in CP Ti Grade 2 and 316L Austenitic Stainless Steel
}

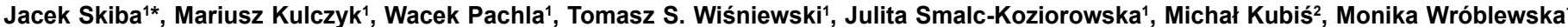 \\ and Mariusz Przybysz ${ }^{1}$
}

1 Institute of High Pressure Physics, Polish Academy of Sciences (Unipress), ul Sokołowska 29, 01-142 Warszawa, Poland

${ }^{2}$ Institute of Heat Engineering, Faculty of Power and Aeronautical Engineering, Warsaw University of Technology, ul Nowowiejska 21/25, 00-665 Warszawa, Poland

\begin{abstract}
A vital problem faced in the implant logical practice is the heat generated due to friction unavoidable during surgical interventions. The proliferation of heat through the implant results in an increase of temperature above the immunological ability of the human tissues. In present study the mechanical, structural, and thermo-physical properties of titanium CP Ti grade 2 and $316 \mathrm{~L}$ stainless steel processed by hydrostatic extrusion (HE) are analyzed and discussed. Effect of severe plastic deformation on the thermo-physical properties is presented. In both the materials the structures obtained were of nanometric scale with an average grain size of $80 \mathrm{~nm}$ in $316 \mathrm{~L}$ steel and $95 \mathrm{~nm}$ in CP Ti grade 2 . After HE, the strength and yield stress increased, with respect to those of the as-received material, respectively by $160 \%$ and $300 \%$ in steel, and $86 \%$ and $120 \%$ in titanium. The thermal diffusivity decreased by $8.5 \%$ in steel and by $7.5 \%$ in titanium, and the specific heat by $8.55 \%$ in steel and $4.5 \%$ in titanium, resulting in $12-13 \%$ decrease of thermal conductivity. All changes were attributed to nanostructure generated during severe plastic deformation by hydrostatic extrusion. The reduced thermo-physical properties widen the possibilities for bioengineering applications of both materials.
\end{abstract}

Keywords: Hydrostatic extrusion; Severe plastic deformation; Grain refinement; Thermophysical properties; Mechanical properties

\section{Introduction}

The increase of temperature in the surroundings of an implant is an essential problem in implantological practice, since it bears the risk of injury to the tissues adjacent to the implant. According to the numerous data available in the literature, the increase of this temperature above the physiological immunity of the tissue may result in its irreversible destruction $[1,2]$. One of the earliest investigations showed that after an excessive thermal exposure the critical temperature above which the bone tissue was irreversibly damaged was $56^{\circ} \mathrm{C}$ [3]. More precise investigations [4-7] which took into account both the temperature and the time of the thermal exposure indicated that the tissue surrounding the implant may be damaged already at much lower temperatures ranging between 40 and $47^{\circ} \mathrm{C}$. The damage may include the blood vessels, denaturation of collagen, and osteocyte necrosis. The increase of the temperature is most often due to the friction which occurs during the preparatory manipulations preceding the implantation such as preparation of hard tissue, drilling the necessary channel in the bone, and corrective grinding of the implant $[8,9]$. The implants, produced commercially in series at the present, usually have unified dimensions and, thus, after their insertion, they require adequate corrections, especially dental implants whose part above the bone must often be mechanically corrected. The machining generates heat in the implant surroundings and may injure the neighboring tissues and hamper the osseointegration, resulting in an idiopathic extraction of the implant. The environment of the oral cavity can also have an adverse effect on the implant-bone integration. Investigations of the influence of the temperature of the consumed food, both liquid and solid, on the heat transfer in the implantation zone have shown that the implant temperature may exceed the physiological immunity of the tissue surrounding the implant [10-12]. For example, after drinking $300 \mathrm{ml}$ of tea with a temperature of $48^{\circ} \mathrm{C}$ the temperature of the implant in the osseointegration can increase to $75^{\circ} \mathrm{C}[10]$.

Materials intended for use in implantology must satisfy the specified requirements such as high impact strength, high mechanical strength, good bio-functionality, and all those without any loss of their biocompatibility with the human organism. This is why the biomaterials are increasingly produced using untypical methods such as severe plastic deformation (SPD). One of these methods, which gives a homogeneous structure both in the transverse and longitudinal cross-section of the processed material, is hydrostatic extrusion (HE) whose effectiveness has been confirmed in numerous literature reports [13-15]. The three-axial compressive stresses active during hydrostatic extrusion in the deformation zone and the advantageous lubrication conditions due to the hydrostatic pressure permit realizing effectively deformation of the material using high reduction per pass with the preservation of the structural and mechanical homogeneity in the entire volume of the processed material. Investigations conducted at the Institute of High Pressure Physics, Polish Academy of Sciences, Unipress (IHPP PAS) since 45 years have confirmed that HE is exceptionally effective in generating severe plastic deformation in various materials, including those which cannot be deformed by classical techniques such as rolling, drawing, or conventional extrusion. This permits the HE-treated nanomaterials to acquire better strength [16-19], fatigue properties [20], impact strength [21], tribological properties [22,23], and corrosion resistance [24]. They also show good biocompatibility $[23,24]$ and higher thermal stability [21,25].

Investigations concerned with the thermo-physical properties of SPD-treated materials are very rare and limited to the classical SPD techniques such as ECAP [26], HPT [27], and ARB [28] which yield materials with a high degree of structural heterogeneity. The

${ }^{*}$ Corresponding author: Jacek Skiba, Institute of High Pressure Physics, Polish Academy of Sciences (Unipress), ul. Sokolowska 29, 01-142 Warszawa, Poland Tel: 48226325010; Fax: 48226324218; E-mail: skiba@unipress.waw.pl

Received: July 11, 2018; Accepted: July 20, 2018; Published: July 23, 2018

Citation: Skiba J, Kulczyk M, Pachla W, Wiśniewski TS, Smalc-Koziorowska J, et al. (2018) Effect of Severe Plastic Deformation Realized by Hydrostatic Extrusion on Heat Transfer in CP Ti Grade 2 and 316L Austenitic Stainless Steel. J Nanomed Nanotechnol 9: 511. doi: 10.4172/2157-7439.1000511

Copyright: ( 2018 Skiba J, et al. This is an open-access article distributed under the terms of the Creative Commons Attribution License, which permits unrestricted use, distribution, and reproduction in any medium, provided the original author and source are credited. 
Citation: Skiba J, Kulczyk M, Pachla W, Wiśniewski TS, Smalc-Koziorowska J, et al. (2018) Effect of Severe Plastic Deformation Realized by Hydrostatic Extrusion on Heat Transfer in CP Ti Grade 2 and 316L Austenitic Stainless Steel. J Nanomed Nanotechnol 9: 511. doi: 10.4172/2157-7439.1000511

Page 2 of 7

scarce reports available in the literature unequivocally show that the refinement of the microstructure results in the restriction of heat transfer. For example, in an AA1060 aluminum alloy processed by ECAP with the cumulated true strain $\varepsilon=9.2$ [29], the refinement of the microstructure reduced the heat transfer as a result of the decrease of the thermo-physical parameters of the material compared to those of the starting material, namely the thermal diffusivity $\alpha$ by $4.2 \%$, specific heat $c_{p}$ by $1.5 \%$, and thermal conductivity $\lambda$ by $6.2 \%$. Similar results were obtained for pure copper in which, after refinement of its microstructure, the thermal conductivity $\lambda$ decreased by $7.5 \%$ compared to that measured before the deformation [30].

In the present study the authors used the HE method for producing ultrafinegrained (UFG) and or nanocrystalline (NC) $\mathrm{CP}$ titanium grade 2 and 316L austenitic steel i.e. two materials with implantological potential. The materials obtained were subjected to structural, mechanical, and thermo-physical examinations. The results were analyzed and the effect of the applied severe plastic deformation and the resulting refinement on the heat transfer in the material was estimated.

\section{Materials and Experimental Methods}

The materials examined were $\mathrm{CP} \mathrm{Ti}$ grade 2 according to the American Standard (2005) with the chemical composition (in wt\%): $0.12 \mathrm{Fe}, 0.02 \mathrm{C}, 0.02 \mathrm{~N}, 0.005 \mathrm{H}, 0.12 \mathrm{O}$, balance $\mathrm{Ti}$, and $316 \mathrm{~L}$ austenitic steel according to the standard 1.4404 (ASTM A 182) with the chemical composition (in wt\%) $0.014 \mathrm{C}, 0.72 \mathrm{Si}, 1.55 \mathrm{Mn}, 16.87 \mathrm{Cr}, 2.02 \mathrm{Mo}$, $0.53 \mathrm{Cu}, 10 \mathrm{Ni}, 0.11 \mathrm{Co}, 0.03 \mathrm{P}, 0.03 \mathrm{~S}, 0.059 \mathrm{~N}$, balance Fe. The basic strength properties of these materials in the starting state are given in Table 1. The initial equivalent grain diameter $d_{2}$ was $29 \mu \mathrm{m}$ in $\mathrm{CP} \mathrm{Ti}$ grade 2 and $35 \mu \mathrm{m}$ in 316L steel where the equivalent grain diameter $d_{2}$ is defined as the diameter of the circle whose surface area is equal to that of the given grain.

In view of the difference in the susceptibility to plastic deformation between the two materials, the HE process parameters were optimized individually for each of them. The process parameters included: reduction per pass $r p p \%$, the strain rate $\dot{\varepsilon}$, the die angle $2 \alpha$ and the lubrication method. The HE process was conducted in a specialized presses, designed and constructed at the IHPP PAS Unipress, with the working pressures up to $1400 \mathrm{MPa}$. The presses were equipped with a system of cooling the extruded product using cold tap water so as to minimize the effect of adiabatic heating [31]. In order to increase the total strain, the extrusion was conducted in three passes (in a cumulative way), using a smaller reduction per pass in each of them, thanks to which the adiabatic heating effects hampering the recovery and recrystallization processes were weakened. CP titanium grade 2 was first extruded from an initial diameter of $50 \mathrm{~mm}$ to a final diameter of $12.5 \mathrm{~mm}$ with the total cumulated true strain $\varepsilon_{\text {cum }}=2.75$, and $316 \mathrm{~L}$ steel - from an initial diameter of $30 \mathrm{~mm}$ to a final diameter of $12.5 \mathrm{~mm}$ with the cumulated true strain $\varepsilon_{\text {cum }}=1.73$. The die angle was $2 \alpha=45^{\circ}$.

The initial microstructures were observed in a Nikon Eclipse LV150 light microscope (LM) and those after the HE - in a JEOL 1200 EX transmission electron microscope (TEM). In both cases the

\begin{tabular}{|c|c|c|c|c|}
\hline & $\begin{array}{c}\text { Ultimate } \\
\text { tensile strength } \\
\text { UTS (MPa) }\end{array}$ & $\begin{array}{c}\text { Yield } \\
\text { strength } \\
\text { YS (MPa) }\end{array}$ & $\begin{array}{c}\text { Elongation } \\
\text { to fracture } \\
\boldsymbol{\varepsilon}_{\boldsymbol{f}} \mathbf{( \% )}\end{array}$ & $\begin{array}{c}\text { Hardness } \\
\boldsymbol{H V O . 2}\end{array}$ \\
\hline CP Ti grade 2 & 543 & 399 & 21 & 185 \\
\hline 316L steel & 593 & 311 & 58 & 223 \\
\hline
\end{tabular}

Table 1: Mechanical properties of CP titanium grade 2 and $316 \mathrm{~L}$ steel in the initial state. observations were made on a transverse cross-section of the sample. The grain size was quantitatively evaluated using the 'Micrometer' software [32] based on the TEM image obtained individually for each sample. After the imaging, at least 200 grains selected randomly from the population, were outlined and the software calculated the equivalent grain diameter $d_{2}$. The mechanical properties were examined using a Zwick Roell Z250 static tensile strength machine with the maximum load of $250 \mathrm{kN}$. The examinations included the ultimate tensile strength $U T S$, the yield strength $Y S$, and the elongation to fracture $\varepsilon_{f}$. The test samples taken from the axis of the rods were $6 \mathrm{~mm}$ in diameter, with the standardized 5:1 proportion and were tested at a tensile strain rate of $0.008 \mathrm{~s}^{-1}$.

The thermal diffusivity was measured by the laser pulse method LFA (Laser Flesh Apparatus) using Netzsch 447 nano flash and 457 micro flash devices. The test samples had cylindrical shapes and were $10 \mathrm{~mm}$ in diameter and $2 \mathrm{~mm}$ high. The LFA analysis was conducted within the temperature range from $50^{\circ} \mathrm{C}$ to $1000^{\circ} \mathrm{C}$ with a heating rate of $3^{\circ} \mathrm{C} \mathrm{min}^{-1}$. In order to increase the emissivity of the samples, they were coated with graphite. The specific heat $c_{p}$ was measured by the differential scanning calorimetry (DSC) using a Netzsch 404 F1 Pegasus calorimeter. The test samples were cylindrical in shape, with a diameter of $5 \mathrm{~mm}$ and mass of $50 \mathrm{mg}$. The DSC analysis was conducted in a neutral argon atmosphere within the temperature range from $50^{\circ} \mathrm{C}$ to $1000^{\circ} \mathrm{C}$ at a heating rate of $10^{\circ} \mathrm{C} \mathrm{min}^{-1}$. In both the LFA and DSC examinations, the samples were taken from the axis of the rods.

The specific heat $c_{p}$ at a given temperature was calculated according to the Standard of the Netzsch company based on the DSC signal [33]:

$$
c_{p}=\frac{m_{\text {standard }}}{m_{\text {sample }}} \cdot \frac{D S C_{\text {sample }}-D S C_{\text {base line }}}{D S C_{\text {standard }}-D S C_{\text {base line }}} \cdot c_{p \text { standard }}\left(\mathrm{J} \mathrm{g}^{-1} \mathrm{~K}^{-1}\right)
$$

where $c_{p \text { standard }}$ is the specific heat of the reference sample (sapphire) in $\left(\mathrm{J} \mathrm{g}^{-1} \mathrm{~K}^{-1}\right), m_{\text {standard }}$ is the reference sample mass (sapphire) in (mg), $m_{\text {sample }}$ is the mass of the examined sample (mg), $D S C_{\text {sample }}$ is the signal of the heat flux obtained in the examined sample at a given temperature $(\mu \mathrm{V})$, and $D S C_{\text {base line }}$ is the signal of the heat flux obtained when the crucible is empty $(\mu \mathrm{V})$, and $D S C_{\text {standard }}$ is the signal of the references sample.

The thermal conductivity was calculated using the commonly known relationship [34]:

$$
\lambda=\rho \cdot a \cdot c_{p}\left(\mathrm{~W} \mathrm{~m}^{-1} \mathrm{~K}^{-1}\right)
$$

Where $\rho$ is the density $\left(\mathrm{g} \mathrm{cm}^{-3}\right), a$ is the thermal diffusivity $\left(\mathrm{mm}^{2}\right.$ $\left.\mathrm{s}^{-1}\right)$, and $c_{p}$ is the specific heat $\left(\mathrm{J} \mathrm{g}^{-1} \mathrm{~K}^{-1}\right)$ according to equation (1).

All the measurements of the thermo-physical parameters were made in the samples in the starting state and after each cumulative HE pass.

\section{Results and Discussion}

\section{Hydrostatic extrusion}

The parameters of the HE process are given in Table 2.

Figure 1a and $\mathrm{b}$ shows the pressure characteristics (variation of pressure vs time) obtained during the extrusion of each of the materials.

As can be seen in Figure 1a, in the extrusion of titanium the pressure was stable (the flat fragments of the characteristic) during each cumulative HE pass, and was $880 \mathrm{MPa}, 695 \mathrm{MPa}$, and $840 \mathrm{MPa}$ during the 1,2 , and $3^{\text {rd }}$ pass respectively. In the $3^{\text {rd }}$ pass, the characteristic 
Citation: Skiba J, Kulczyk M, Pachla W, Wiśniewski TS, Smalc-Koziorowska J, et al. (2018) Effect of Severe Plastic Deformation Realized by Hydrostatic Extrusion on Heat Transfer in CP Ti Grade 2 and 316L Austenitic Stainless Steel. J Nanomed Nanotechnol 9: 511. doi: 10.4172/2157-7439.1000511

Page 3 of 7

shows a violent rise of breakthrough pressure (peak on the pressure characteristic) at which the material begins to flow out from the die. The pressure peak exceeds the extrusion pressure $p_{H E}$ by more than $160 \mathrm{MPa}$. This is so because of the strong strengthening of the material during the two preceding HE passes and, hence, the necessity that the material must overcome not only static friction but also the yield strength of the material i.e. occurs above $Y S=830 \mathrm{MPa}$ (Figure 2).

The pressure characteristics obtained in extrusion of $316 \mathrm{~L}$ steel are also stable (Figure $1 \mathrm{~b}$ ). Because of the much stronger deformation strengthening of this material compared to that occurring in titanium, all the pressure characteristics show high breakthrough pressure - which is associated with the plasticizing of the material (overcoming the yield strength) and the beginning of its extrusion. The highest breakthrough pressure appears during the $2^{\text {nd }}$ pass of the process conducted with a high unit true strain $\varepsilon=0.57$ at which $Y S$ exceeded $1000 \mathrm{MPa}$ (Figure 2). Because of the stronger deformation strengthening of $316 \mathrm{~L}$ steel, the successive passes of the cumulative HE were started from smaller diameter $(30 \mathrm{~mm})$ than in case of titanium $(50 \mathrm{~mm})$. In effect the total plastic deformation for $316 \mathrm{~L}$ was smaller by almost $40 \%$ than that achieved in titanium.

Many literature reports concerning HE describe the effect of strong adiabatic heating which occurs during the process $[13,15,35]$. This is associated with the transformation of the mechanical work done during the plastic deformation by HE into heat. As shown among others in reference [36], the amount of heat is directly proportional to the extrusion pressure, inversely proportional to the density and specific heat of the material, and depends on the percent of the mechanical work transformed into heat which in HE is high and can amount to $95 \%$. The value of $T / T$ due to adiabatic heating calculated in the present experiments was $\sim 0.3$ in both materials, where $T$ is the temperature measured during the $\mathrm{HE}$ and $T_{m}$ is the melting temperature of the material (both given in Kelvin degrees) Table 2. That the values obtained in the two materials are the same is associated with the very similar values of their specific heat $\left(0.55 \mathrm{~J} \mathrm{~g}^{-1} \mathrm{~K}^{-1}\right.$ in titanium and 0.52 $\mathrm{J} \mathrm{g}^{-1} \mathrm{~K}^{-1}$ in steel), and with the higher extrusion pressure applied to steel (higher by $100 \mathrm{MPa}$ on average) than that in titanium, which compensates for the lower $T_{m}$ and the almost two times higher density of $316 \mathrm{~L}$ steel. The comparable values of the adiabatic heat obtained in both materials could indicate that its effect on the initiation of the recovery and recrystallization processes should also be similar. This would be so if only the twentyfold difference in the stacking fault energy (SFE) between them was not so high: steel 316L is classified among the materials with the lowest SFE $\left(\sim 14 \mathrm{~mJ} \mathrm{~m}^{-2}\right)$ whereas CP Ti grade 2 has a high SFE (310 $\left.\mathrm{mJ} \mathrm{m}^{-2}\right)$ [37]. Hence the recovery (polygonization) in steel occurs easier whereas the edge dislocation climbing and transverse slide are more difficult which results in the stored deformation energy being here greater and, in consequence, the higher extrusion pressure at much lower deformations than those in CP Ti grade 2.

\section{Microstructure}

In the SPD processes, the factors which are directly responsible for the changes of the mechanical and thermo-physical properties of the treated materials is the evolution of their microstructure i.e. its significant refinement, and the generation of numerous structural defects. In many applications of CP Ti grade 2 and 316L steel, especially in bio-engineering, it is of great importance that the properties of the material should be homogeneous. Both the metals obtained in the present experiments after achieving the critical plastic deformation had homogeneous nanometric structures with well-shaped grains and a low density of internal defects (Figures 3 and 4 ).

Figure 3a-c shows the microstructure of $\mathrm{CP}$ Ti grade 2 after the successive HE cumulative hydrostatic extrusion. After the first stage (Figure 3a) we can see the primary grains with visible defects inside them formed due to the deformation. If the deformation degree is too

\begin{tabular}{|c|c|c|c|c|c|c|c|c|}
\hline Notation & $\begin{array}{c}\mathrm{HE} \\
\text { pass }\end{array}$ & $\begin{array}{c}\text { Billet } \\
\text { diameter } \\
d_{0}(\mathrm{~mm})\end{array}$ & $\begin{array}{c}\text { Product } \\
\text { diameter } \\
d_{f}(\mathrm{~mm})\end{array}$ & $\begin{array}{l}\text { True } \\
\text { strain } \\
\varepsilon=\ln R\end{array}$ & $\begin{array}{c}\text { Cumulative } \\
\text { true strain } \\
\varepsilon_{\text {cum }}\end{array}$ & $\begin{array}{c}T_{\text {adiabatic }} \\
\left({ }^{\circ} \mathrm{C}\right)\end{array}$ & $T / T_{m}$ & $\begin{array}{c}\text { Extrusion } \\
\text { pressure } \\
p_{H E}(\mathrm{MPa})\end{array}$ \\
\hline Ti gr.2_1 & 1 & 50 & 27.9 & 1.16 & 1.16 & 355 & 0.32 & 880 \\
\hline Tigr.2_2 & 2 & 27.9 & 17.9 & 0.88 & 2.05 & 280 & 0.29 & 695 \\
\hline Tigr.2_3 & 3 & 17.9 & 12.5 & 0.71 & 2.76 & 340 & 0.32 & 840 \\
\hline 316L_1 & 1 & 30 & 19.9 & 0.82 & 0.82 & 245 & 0.31 & 900 \\
\hline 316L_2 & 2 & 19.9 & 15 & 0.57 & 1.39 & 280 & 0.33 & 1025 \\
\hline 316L_3 & 3 & 15 & 12.6 & 0.34 & 1.73 & 235 & 0.29 & 785 \\
\hline
\end{tabular}

Table 2: Basic process parameters adopted in the hydrostatic extrusion of CP Ti grade 2 and 316L steel.
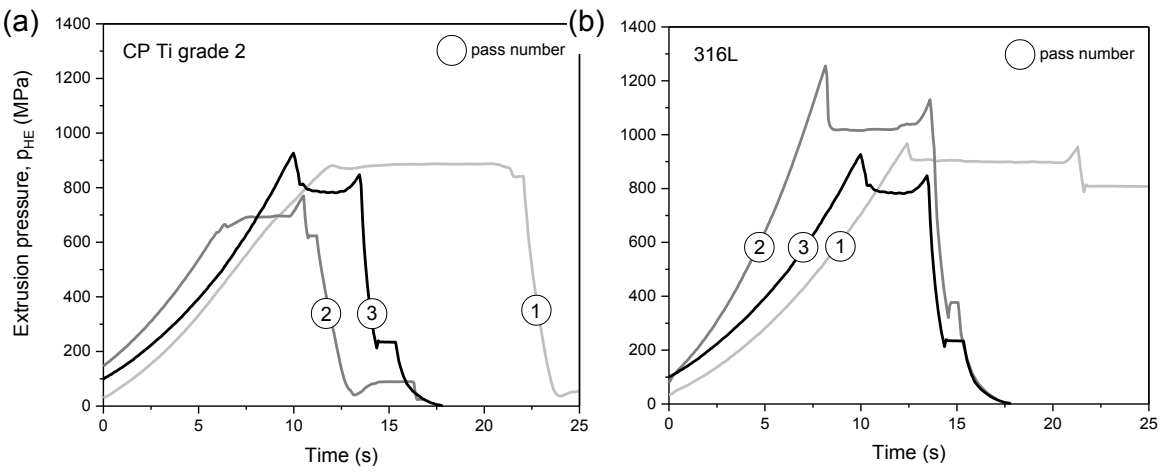

Figure 1: The pressure characteristics (variation of pressure vs. time) obtained during the extrusion of each of the materials. 
Citation: Skiba J, Kulczyk M, Pachla W, Wiśniewski TS, Smalc-Koziorowska J, et al. (2018) Effect of Severe Plastic Deformation Realized by Hydrostatic Extrusion on Heat Transfer in CP Ti Grade 2 and 316L Austenitic Stainless Steel. J Nanomed Nanotechnol 9: 511. doi: 10.4172/2157-7439.1000511

Page 4 of 7

low, the refinement of the microstructure is only slight. After the next extrusion stage (Figure $3 \mathrm{~b}$ ), the is already strongly refined (the average grain size is about $100 \mathrm{~nm}$ ) with a high defect density and regions of sub-grains with small misorientation angles, After the third stage of the extrusion (Figure $3 \mathrm{c}$ ) in which the deformation increases to $\varepsilon_{\text {cum }}=$ 2.75 , well-shaped nanograins (the average grain size $\sim 95 \mathrm{~nm}$ ) appear on the entire cross-section of the sample. The dominant mechanism of the structural refinement is the dynamic recovery which in effect leads to well-marked polygonization and low stored energy.

Figure 4 shows the microstructure of $316 \mathrm{~L}$ steel after the successive extrusion passes. As can be seen its microstructure differs markedly from that of CP Ti grade 2. After the first extrusion pass (Figure 4a), the

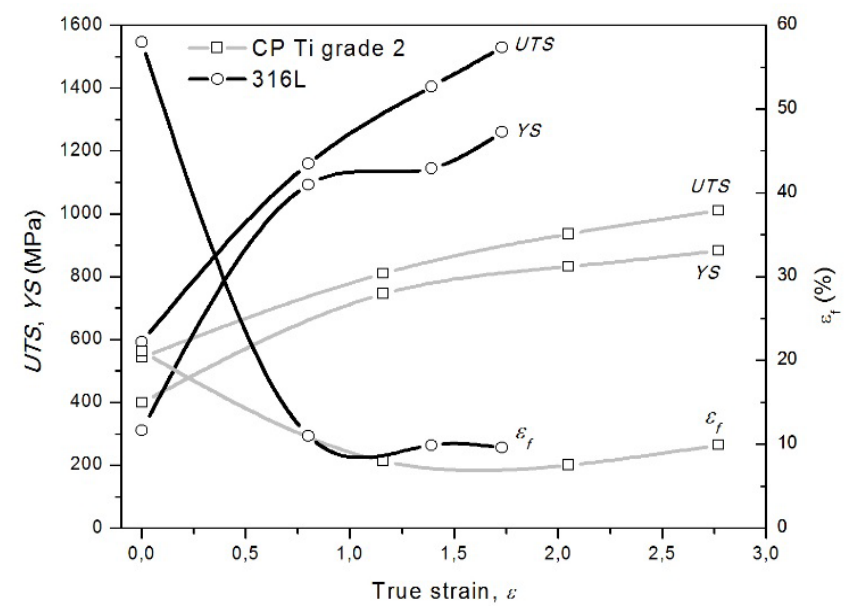

Figure 2: Variation of the ultimate tensile strength UTS, yield stress $Y S$ and elongation to fracture $\varepsilon_{f}$ with increasing true strain during cold hydrostatic extrusion: CP Ti grade 2, 316 L stainless steel. microstructure is strongly defected with well visible shear bands 250 $300 \mathrm{~nm}$ wide. The next extrusion pass gave a strongly refined structure, the reduction of the width of the shear bands to $\sim 100 \mathrm{~nm}$, and a twin structure of severely deformed austenitic steel. The further increase of deformation to $\varepsilon_{\text {cum }}=1.73$ (Figure $4 \mathrm{~b}$ and $4 \mathrm{c}$ ) resulted in the appearance of slip bands and well-shaped grains with an average diameter of 80 $\mathrm{nm}$. The character of the grains indicates that dynamic recrystallization has occurred and the density of defects that high deformation energy has been stored in material.

\section{Strength properties}

Figure 2 shows the variation of the ultimate tensile stress (UTS), yield stress $(Y S)$, and the elongation to fracture $\left(\varepsilon_{f}\right)$ as a function of true strain $\varepsilon$ in $\mathrm{CP}$ Ti grade 2 and $316 \mathrm{~L}$ steel during their hydrostatic extrusion. In both materials the mechanical strength increases with increasing cumulated deformation strain but in $316 \mathrm{~L}$ steel the deformation strengthening effect is much stronger than in CP titanium grade 2 . The highest strengthening takes place during the $1^{\text {st }}$ extrusion pass (YS increases by $85 \%$ in $\mathrm{Ti}$ and $250 \%$ in steel) with its final total increase to $120 \%$ in titanium and above $300 \%$ in steel. This difference is associated with the lower stored deformation energy in titanium because of the easier climbing and transverse slip of the dislocations (i.e. the recovery processes) in this material (Figure $3 b$ and $3 c$ ). In steel, on the other hand, the recovery processes are impede and, in consequence, the density and entanglement of the moving dislocations increases thereby drastically increasing the deformation strengthening degree as early as during the $1^{\text {st }}$ pass of the extrusion (Figure $4 \mathrm{a}$ ). As a result of this strong strengthening, the initiation of thermally-activated structural changes associated with the movement and annihilation of defects is difficult and shifted to further extrusion passes (Figures $4 \mathrm{~b}$ and c). Because of the higher melting temperature $T_{m}$ of titanium compared to that of steel, the refinement of its structure is easier, and, at the maximum cumulated true strain, the adiabatic heating effect contributes to an additional slight increase of the material ductility $\left(\varepsilon_{f}\right)$ (Figure 2).
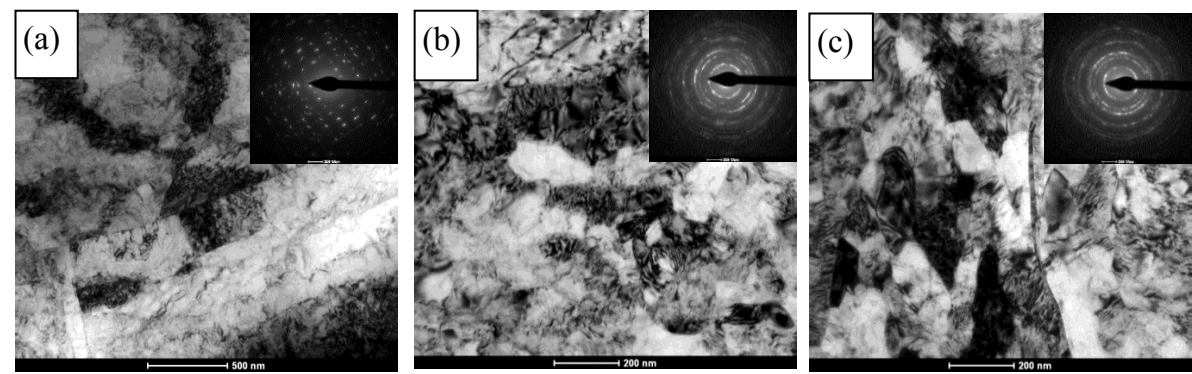

Figure 3: Microstructure of $\mathrm{CP}$ Ti grade 2 after cumulative hydrostatic extrusion a) $1^{\text {st }}$ pass $\varepsilon=1.16$, b) $2^{\text {nd }}$ pass $\varepsilon_{\text {cum }}=2.05$, c) $3^{\text {rd }}$ pass $\varepsilon_{\text {cum }}=2.75$.
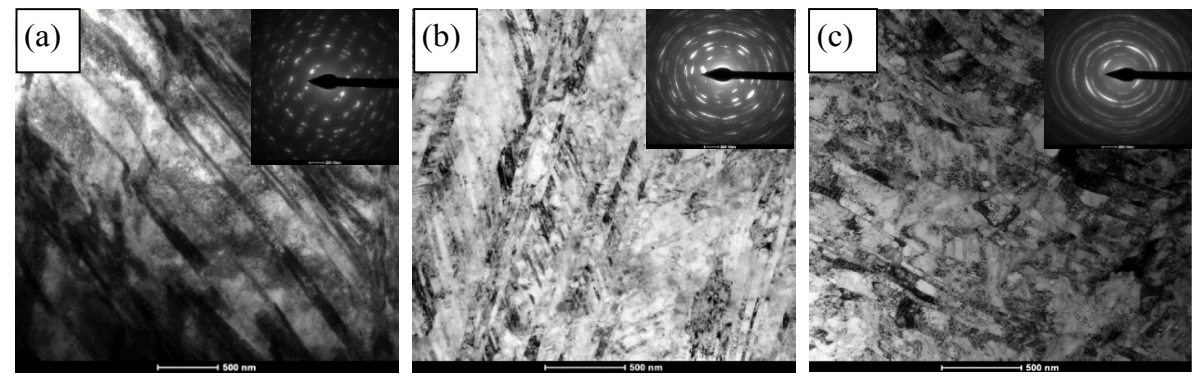

Figure 4: Microstructure of $316 \mathrm{~L}$ stainless steel after cumulative hydrostatic extrusion: a) $1^{\text {st }}$ pass $\varepsilon=0.8$, b) $2^{\text {nd }}$ pass $\varepsilon_{\text {cum }}=1.39$, c) $3^{\text {rd }}$ pass $\varepsilon_{\text {cum }}=1.73$. 
Citation: Skiba J, Kulczyk M, Pachla W, Wiśniewski TS, Smalc-Koziorowska J, et al. (2018) Effect of Severe Plastic Deformation Realized by Hydrostatic Extrusion on Heat Transfer in CP Ti Grade 2 and 316L Austenitic Stainless Steel. J Nanomed Nanotechnol 9: 511. doi: 10.4172/2157-7439.1000511

Page 5 of 7

\section{Thermo-physical properties}

Thermal diffusivity $\alpha$ : In both the materials examined the thermal diffusivity $\alpha$ decreases significantly with increasing plastic deformation, Figure 5 . In titanium, the maximum decrease by $\sim 7.5 \%$ already occurred after the $2^{\text {nd }}$ extrusion pass and was maintained untill the completion of the $3^{\text {rd }} \mathrm{HE}$ pass conducted at the highest total cumulated true strain $\varepsilon_{\text {cum }}=2,75$. Contrary to the situation in titanium, in steel the thermal diffusivity decreases progressively till the maximum cumulated true strain $\varepsilon_{\text {cum }}=1.73$. In materials with an UFG and NC structure, the decrease of the thermal diffusivity is closely related with the limited motion of energy quanta (phonons) due to the large number of structural defects (point, linear, and spatial) which were formed during processing of these materials and which constituted an effective barrier to heat exchange [38]. The effect of the microstructure refinement on the increase of thermal diffusivity after HE has only been investigated in ductile materials such as copper and aluminum but not in titanium and austenitic steel. For example, Lee [29] subjected the AA1060 aluminum alloy to 8 passes of ECAP at the cumulated true strain $\varepsilon=9.2$ and obtained the decrease of its thermal diffusivity by $\sim 4 \%$ with respect to that of the starting material. This result was, due, on the one hand, to the high susceptibility of aluminum to recovery and recrystallization which annihilate the defects and weaken the deformation strengthening of the material and, on the other hand, to the lower effectiveness of the generation of structural defects during ECAP compared to that possible to achieve in HE.

Specific heat $\mathrm{c}_{\mathrm{p}}$ : Specific heat is at the present often determined by differential scanning calorimetry (DSC) which permits determining not only the specific heat but also the temperature peaks due to the thermally-activated recovery and recrystallization processes [39-41].

As can be seen in Figure 6, in both CP Ti grade 2 and $316 \mathrm{~L}$ steel processed by severe plastic deformation the specific heat $c_{p}$ decreases with respect to that of the starting material and reaches a minimum after the $2^{\text {nd }} \mathrm{HE}$ pass. There is however difference between these two materials in that in titanium the specific heat decreases by $9.6 \%$ which is twice as much as in steel where it decreases by $4.7 \%$. This is so since in titanium, which is a material with lower stored plastic deformation energy compared with that in steel, easier polygonization, and easier annihilation of structural defects during the recovery process, the yield stress YS is lower than that in steel by almost $40 \%$ (830 $\mathrm{MPa}$ in titanium compared to $1150 \mathrm{MPa}$ in steel). As can be seen in Figure 6, after achieving the maximum deformation degree during the $3^{\text {rd }} \mathrm{HE}$ stage, in titanium the $c_{p}$ value is stabilized whereas in steel it markedly increases by $6.5 \%$. This difference can be attributed to the intensive dynamic recrystallization which proceeds in $316 \mathrm{~L}$ steel after SPD at lower temperatures (Figure 4c), i.e. to the annihilation of structural defects which in CP Ti grade 2 occurs during the dynamic recovery in the first two HE passes (Figure $3 b$ ).

Figure 7 shows the DSC results obtained for CP titanium grade 2. It can be seen that the recovery and recrystallization temperatures are evidently shifted towards lower values. The initiation temperature of the recovery process decreases from $\sim 480^{\circ} \mathrm{C}$ in the starting material to $\sim 280^{\circ} \mathrm{C}$ after the maximum true strain $\varepsilon_{\text {cum }}=2.75$ during the $3^{\text {rd }} \mathrm{HE}$ pass. The recrystallization initiation temperature decreases from $660^{\circ} \mathrm{C}$ to $570^{\circ} \mathrm{C}$, respectively. For comparison with other literature reports, we can mention the results presented in reference [42] concerning the DSC results obtained in titanium processed by ECAP. The DSC analysis showed the decrease of the recovery initiation temperature from $440^{\circ} \mathrm{C}$ after one ECAP pass

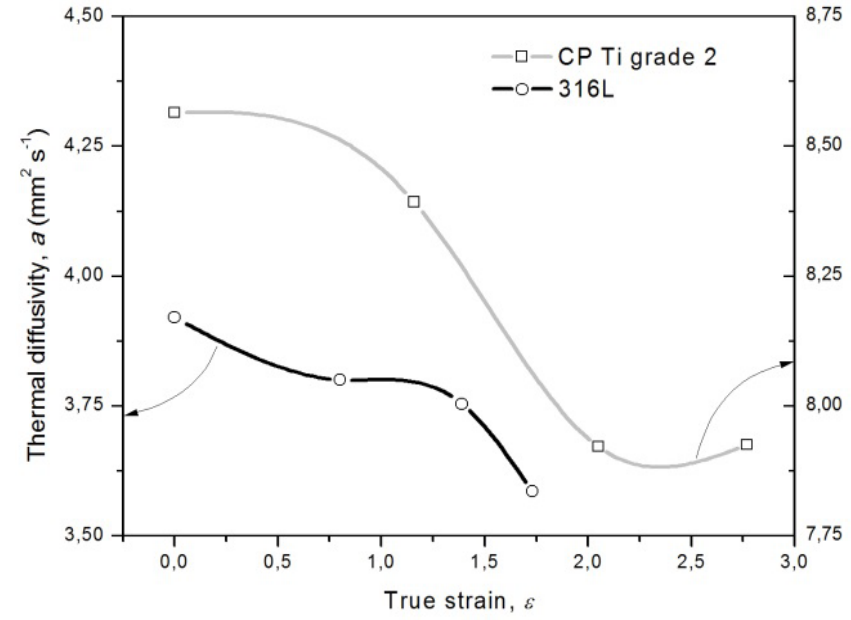

Figure 5: Variation of the thermal diffusivity with increasing true strain in $\mathrm{CP} T$ grade 2 and $316 \mathrm{~L}$ steel during cumulative cold hydrostatic extrusion.

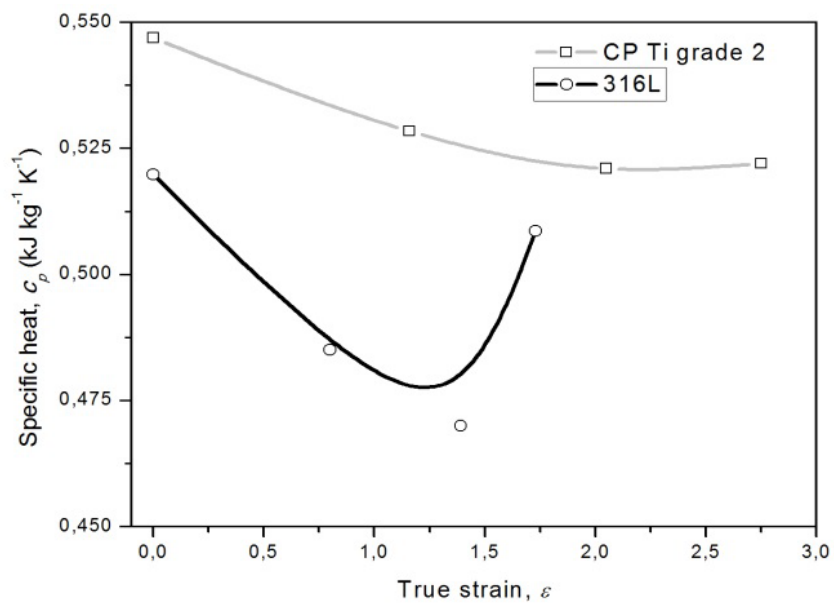

Figure 6: Variation of the specific heat $c_{p}$ with increasing true strain in $\mathrm{CP} \mathrm{Ti}$ grade 2 and $316 \mathrm{~L}$ steel during cumulative cold hydrostatic extrusion.

to $310^{\circ} \mathrm{C}$ after three ECAP passes i.e. by $40 \%$. Comparing this result with the $70 \%$ decrease of the recovery initiation temperature achieved in our study, we can see that HE is more effective in the generation of high-energy defects.

In $316 \mathrm{~L}$ steel (Figure 8), the DSC analysis shows greater differences in the heat transfer during the HE stage conducted at the highest true strain. After the $1^{\text {st }}$ and $2^{\text {nd }} \mathrm{HE}$ passes, the DSC characteristics and the recovery temperatures are similar and indicate that intensive recovery and annihilation of defects then proceed. These effects are much weaker in the starting material and after the $3^{\text {rd }} \mathrm{HE}$ pass $\left(\varepsilon_{\text {cum }}=1.73\right)$ which results from the evident ordering of the structure and elimination of dislocations (Figure 5). The structure obtained is nanometric with wellshaped grains and free of dislocations in which the high-energy defects are annihilated at grain boundaries, which, among other factors, is the reason why the specific heat $c_{p}$ of steel increases after the $3^{\text {rd }} \mathrm{HE}$ pass, Figure 6 . The tendency of the recovery temperature to increase and the recrystallization temperature to decrease after the maximum deformation is in CP Ti grade 2 and $316 \mathrm{~L}$ steel similar but in steel it is more pronounced. 
Citation: Skiba J, Kulczyk M, Pachla W, Wiśniewski TS, Smalc-Koziorowska J, et al. (2018) Effect of Severe Plastic Deformation Realized by Hydrostatic Extrusion on Heat Transfer in CP Ti Grade 2 and 316L Austenitic Stainless Steel. J Nanomed Nanotechnol 9: 511. doi: 10.4172/2157-7439.1000511

Page 6 of 7

Thermal conductivity $\lambda$ : Table 3 gives the measured values of the thermal diffusivity $a$, the specific heat $c_{p}$ calculated from formula (1), and the thermal conductivity $\lambda$ calculated from formula (2).

In both metals, as the deformation increases, the thermal conductivity decreases (with respect to that in the as-received material) with the maximum decrease by $12 \%$ in CP Ti grade 2 and $13 \%$ in $316 \mathrm{~L}$ steel occurring during the $2^{\text {nd }} \mathrm{HE}$ pass. After the final deformation pass $\lambda$ slightly increases especially in $316 \mathrm{~L}$ steel which is associated with the well-marked change in the specific heat characteristic observed in this material during the final HE pass (Figure 6).

The present investigations have shown that, in CP Ti grade 2 and 316L steel, the SPD process conducted at high true strains and the resulting refinement of the microstructure reduce advantageously the heat exchange in the material. This is of special importance from the point of view of bio-engineering, since by decreasing the temperature generated in the implant and its surroundings even by a few percent;

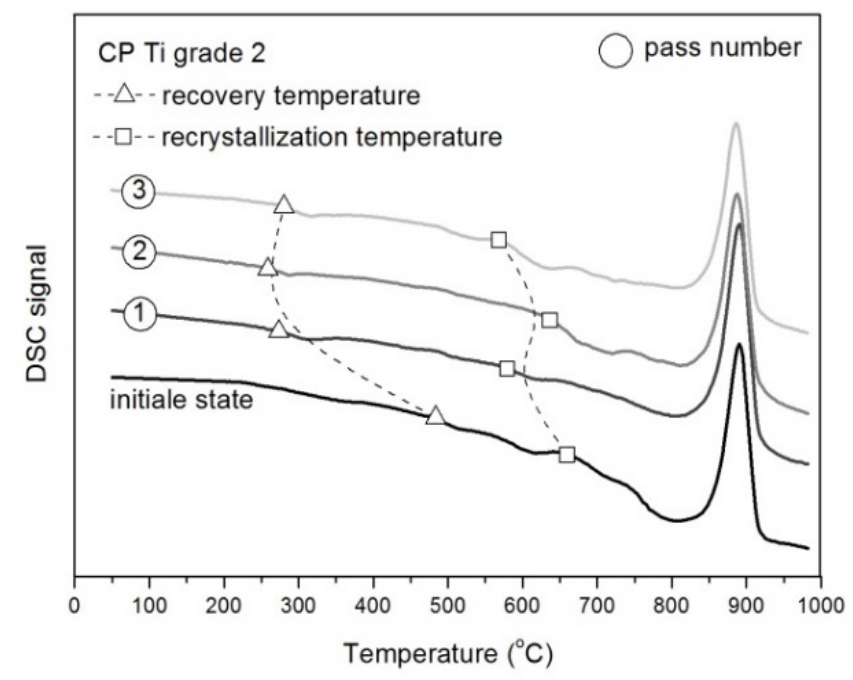

Figure 7: Recovery and recrystallization temperature in CP Ti grade 2 after hydrostatic extrusion (DSC results).

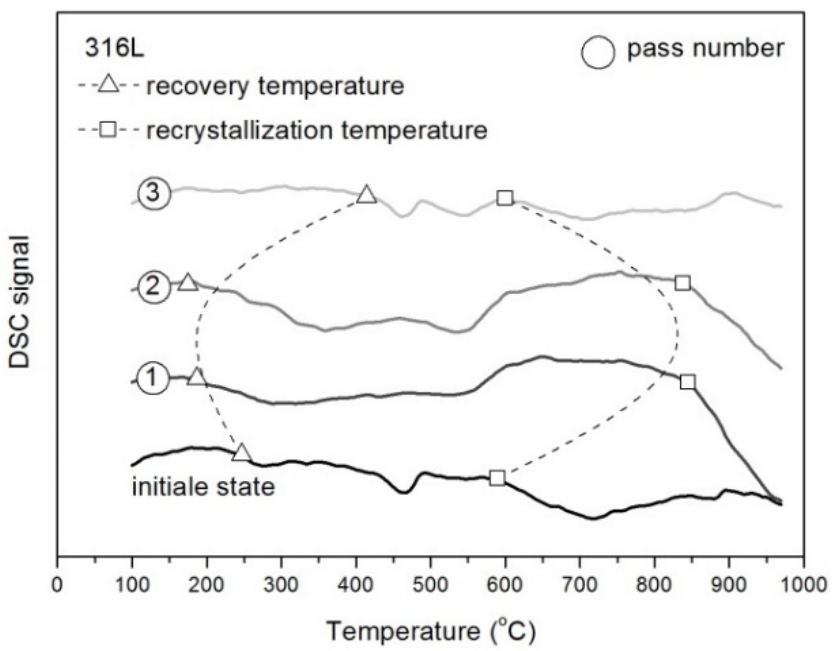

Figure 8: Recovery and recrystallization temperatures in 316L after hydrostatic extrusion (DSC results).

\begin{tabular}{|c|c|c|c|c|}
\hline Notation & $\begin{array}{c}\text { Cumulative } \\
\text { True strain } \\
\varepsilon_{\text {cum }}\end{array}$ & $\begin{array}{c}\text { Thermal } \\
\text { diffusivity } \\
a\left(\mathrm{~mm}^{2} \mathrm{~s}^{-1}\right)\end{array}$ & $\begin{array}{c}\text { Specific } \\
\text { heat } \\
c_{p}\left(\mathbf{k J ~ k g ~}^{-1} \mathbf{K}^{-1}\right)\end{array}$ & $\begin{array}{c}\text { Thermal } \\
\text { conductivity } \\
\lambda\left(\mathrm{W} \mathrm{m}^{-1} \cdot \mathrm{K}^{-1}\right)\end{array}$ \\
\hline CP Ti gr.2 AR & 0 & 8.56 & 0.55 & 20.38 \\
\hline CP Ti gr.2_1 & 1.16 & 8.39 & 0.53 & 19.30 \\
\hline CP Ti gr.2_2 & 2.05 & 7.92 & 0.52 & 17.96 \\
\hline CP Ti gr.2_3 & 2.76 & 7.93 & 0.52 & 18.00 \\
\hline 316L AR & 0 & 3.92 & 0.52 & 16.24 \\
\hline 316L_1 & 0.82 & 3.8 & 0.49 & 14.69 \\
\hline $316 \mathrm{~L} \_2$ & 1.39 & 3.75 & 0.47 & 14.06 \\
\hline 316L_3 & 1.73 & 3.58 & 0.51 & 14.53 \\
\hline $\mathrm{AR}$ - as received & & & & \\
\hline
\end{tabular}

Table 3: Thermal diffusivity, specific heat, and thermal conductivity of CP Ti grade 2 and $316 \mathrm{~L}$ steel in the as -received state and after the successive passes of cumulative hydrostatic extrusion.

we can avoid damage to the tissue adjacent to the implant and in consequence ensure the successful osseo integration during the necessary surgical interventions.

\section{Conclusion}

The results obtained in the present study concerning the effect of cumulative hydrostatic extrusion on the microstructure and properties of CP Ti grade 2 and $316 \mathrm{~L}$ steel confirmed the effectiveness of this technology as one of the SPD techniques used for refining the microstructure of materials to the ultrafinegrained (UFG) and nanocrystalline (NC) level. After the HE process conducted with the cumulated true strain $\varepsilon_{\text {cum }}=2.75$ in titanium and $\varepsilon_{\text {cum }}=1.73$ in $316 \mathrm{~L}$ steel, the average grain size was $d_{2}=95 \mathrm{~nm}$ in titanium and $d_{2}=80 \mathrm{~nm}$ in steel. In both materials, the refinement of the microstructure resulted in a significant improvement of the strength properties with respect to those of the starting material. The yield strength YS increased by $80 \%$ in CP Ti grade 2 and $160 \%$ in $316 \mathrm{~L}$ steel, with the corresponding decrease of the plasticity $\varepsilon_{f}$ by $40 \%$ in titanium and $46 \%$ in steel at the maximum plastic deformation $\varepsilon_{\text {cum }}$ $=2.76$ and $\varepsilon_{\text {cum }}=173$, respectively. The differences between the two materials directly result from the difference in their susceptibility to the recovery and recrystallization processes and this, in turn, is associated with the more than 20 -fold difference in their stacking fault energy (SFE). Thanks to the nanostructure generated in these materials, their thermo-physical properties were obviously reduced, namely, the thermal diffusivity $a$ decreases by $7.5 \%$ in titanium and $8.5 \%$ in steel, the specific heat $c_{p}$ - by $4.5 \%$ in titanium and $9.6 \%$ in steel, and the thermal conductivity $\lambda$ - by $11.5 \%$ in titanium and $13.5 \%$ in steel. This effect was due to the numerous structural defects, formed in the material during the SPD deformation, which constitute an effective barrier to heat flow.

The results obtained during the present study open the possibilities for bioengineering applications of the materials subjected to severe plastic deformation realized by hydrostatic extrusion. The advantages of these materials compared to those commercially available are their better strength properties combined with the limited heat transfer due to reduced thermo-physical properties. This creates favorable conditions for their safe implantation in the human organism without the risk of degradation of the implant material and the adjacent tissues during the necessary surgical interventions and during the day-to-day exploitation.

\section{Acknowledgment}

This work was carried out within the PRELUDIUM 9 Project financed by the National Science Centre under the contract no. 2015/17/N/ST8/01471. 
Citation: Skiba J, Kulczyk M, Pachla W, Wiśniewski TS, Smalc-Koziorowska J, et al. (2018) Effect of Severe Plastic Deformation Realized by Hydrostatic Extrusion on Heat Transfer in CP Ti Grade 2 and 316L Austenitic Stainless Steel. J Nanomed Nanotechnol 9: 511. doi: $10.4172 / 2157-7439.1000511$

\section{References}

1. Matthews LS, Hirsch C (1972) Temperatures measured in human cortical bone when drilling. J Bone Join Surg Am 54: 297-308.

2. Lundskog J (1972) Heat and bone tissue. An experimental investigation of the thermal properties of bone and threshold level for thermal injury. Scand J Plast Reconstr Surg 9: 1-80.

3. Eriksson RA, Albrektsson T (1984) The effect of heat on bone regeneration: an experimental study in the rabbit using the bone growth chamber. J Oral Maxillofac Surg 42: 705-711.

4. Eriksson A, Albrektsson T, Grane B (1982) Thermal injury to bone. A vitalmicroscopic description of heat effects. J Oral Maxillofac Surg 11: 115-121.

5. Eriksson A, Albrektsson T (1983) Temperature threshold levels for heatinduced bone tissue injury: A vital-microscopic study in the rabbit. J Prosthe Dent 50: 101-107.

6. Eriksson A, Albrektsson T, Magnusson B (1984) Assessment of bone viability after heat trauma. A histological, histochemical and vital microscopic study in rabbit. Scand J Plast Reconstr Surg Hand Surg 18: 261-268.

7. Benington IC, Biagoni PA, Briggs J (2002) Thermal changes observed at implant sites during internal and external irrigation. Clin Oral Implants Res 13: 293-297.

8. Huang CC, Liu YC, Chen LW, Chen YC (2010) Temperature rise of alveolar bone during dental implant drilling using the finite element simulation. Life Sci J 7: 68-72.

9. Karaca F, Aksakal B (2013) Effect of various drilling parameters on bone during implantology: An in vitro experimental stud. Acta Bioeng Biomech 15: 25-32.

10. Ormianer Z, Feuerstin O, Assad R, Samet N, Weiss El (2009) In vivo changes in dental implant temperatures during hot beverage intake: A pilot study. Implant Dent 18: 38-45

11. Wong K, Boyde A, Howell PGT (2001) A model of temperature transients in dental implants. Biomaterials 22: 2795-2797.

12. Palmer DS, Barco MT, Billy EJ (1992) Temperature extremes produced orally by hot and cold liquids. J Prosthet Dent 67: 325-327.

13. Pachla W, Skiba J, Kulczyk M, Przybysz S, Przybysz M, et al. (2014) Nanostructurization of $316 \mathrm{~L}$ type austenitic stainless steels by hydrostatic extrusion. Mater Sci Eng A 615: 116-127.

14. Pachla W, Kulczyk M, Sus-Ryszkowska M, Mazur A, Kurzydlowski KJ (2008) Nanocrystalline titanium produced by hydrostatic extrusion. J Mater Process Tech 205: 173-182.

15. Pachla W, Kulczyk M, Przybysz S, Skiba J, Wojciechowski K, et al. (2015) Effect of severe plastic deformation realized by hydrostatic extrusion and rotary swaging on the properties of CP Ti grade 2. J Mater Process Tech 221: $255-268$

16. Pachla W, Kulczyk M, Swiderska-Sroda A, Lewandowska M, Garbacz H, et al. (2006) Nanostructuring of metals by hydrostatic extrusion. Proceedings of 9th International Conference on Metal Forming EMRS: 535-538.

17. Pachla W, Kulczyk M, Mazur A, Sus-Ryszkowska M (2009) UFG and nanocrystalline microstructures produced by hydrostatic extrusion of multifilament wires. Int J Mater Res 100: 1-7.

18. Kulczyk M, Pachla W, Świderska-Środa A, Krasilnikov N, Diduszko R, et al. (2006) Combination of ECAP and Hydrostatic Extrusion for UFG microstructure generation in nickel. Solid State Phenomena 114: 51-56.

19. Kulczyk M, Skiba J, Przybysz S, Pachla W, Bazarnik P, et al. (2012) High strength silicon bronze (CuSi $\mathrm{Mn}$ ) made by hydrostatic extrusion. Arch Metal Mater 57: 859-862.

20. Garbacz H, Pakieła Z, Kurzydłowski KJ (2010) Fatique properties of nanocrystalline titanium. Rev Adv Mater Sci 25: 256-260.

21. Oksiuta Z, Lewandowska M, Kurzydłowski KJ, Baluc N (2010) Reduced activation ODS ferritic steel - recent development in high speed hot extrusion processing. Phys Status Solidi A 207: 1128-1131.
22. Budniak J, Lewandowska M, Pachla W, Kulczyk M, Kurzydłowski KJ (2006) The Influence of Hydrostatic Extrusion on the Properties of an Austenitic StainlessSteel. Solid State Phenomena 114: 57-62.

23. Garbacz H, Gradzka-Dahlke M, Kurzydłowski KJ (2007) The tribological properties of nano-titanium obtained by hydrostatic extrusion. Wear 263 : 572-578.

24. Pisarek M, Kędzierzawski P, Janik-Czachor M, Kurzydłowski KJ (2007) The effect of hydrostatic extrusion on resistance of 316 austenitic stainless steel to pit nucleation. Electrochem Commun 9: 2463-2466.

25. Garbacz H (2010) Effect of nanostructure on the Ti Grade2 properties Inżynieria Materiałowa 3: 777-780.

26. Gendelman OV, Shapiro M, Estrin Y, Hellmig RJ, Lekhtmakher S (2006) Grain size distribution and heat conductivity of copper processed by equal channel angular pressing. Mater Sci Eng A 434: 88-94.

27. Jiang H, Zhu YT, Butt DP, Alexandrov IV, Lowe TC (2000) Microstructural evolution, microhardness and thermal stability of HPT - processed $\mathrm{Cu}$. Mater Sci Eng A 290: 128-138.

28. Kwan C, Wang Z, Kang S (2000) Mechanical behavior and microstructura evolution upon annealing of the accumulative roll-bonding (ARB) processed $A$ alloy 1100 . volution, microhardness and thermal stability of HPT - processed Cu. Mater Sci Eng A 290: 128-138.

29. Lee S, Kwon S (2012) Thermal conductivity of aluminium fabricated by equal Channel angular pressing. XX IMEKO World Congress, Busan, Republic of Korea.

30. Hellmig RJ, Janecek M, Hadzima B, Gendelman OV, Shapiro M, et al. (2008) A portrait of copper processed by equal channel angular pressing. Mater Trans 49: 31-37.

31. Pachla W, Skiba J, Kulczyk M, Przybysz M, Wojciechowski K (2015) Highpressure equipment for cold severe plastic deformation working of materials Obróbka Plastyczna Metali 26: 283-306.

32. Wejrzanowski T, Spychalski WL, Różniatowski K, Kurzydłowski KJ (2008) Image based analysis of complex microstructures of engineering materials. Int J Appl Math Comput Sci 18: 33-39.

33. Manufacturer's data: Differential Scanning Calorymetry DSC 404 F1 Pegasus, Netzsch - Gerätebau GmbH.

34. Cengel YA, Ghajar AJ (2015) Heat and Mass Transfer: Fundamentals and Applications, ( $5^{\text {th }}$ Edtn), McGraw-Hill Education, NY 10121, USA.

35. Pachla W, Kulczyk M, Smalc-Koziorowska J, Wróblewska M, Skiba J, et al. (2017) Mechanical properties and microstructure of ultrafine grained commercial purity aluminium prepared by cryo-hydrostatic extrusion. Mater Sci Eng A 695: 178-192.

36. Campos MF, Loureiro SA, Rodrigues D, Carmo Silva M, Lima NB (2008) Estimative of the Stacking Fault Energy for a FeNi(50/50) Alloy and a 316L Stainless Steel. Mater Sci Forum 591: 3-7.

37. Guo Z, Miodownik AP, Saunders N, Schille JP (2006) Influence of stacking fault energy on high temperature creep of alpha titanium alloys. Scr Mater 54 2175-2178.

38. Kittel C (1976) Wstęp do fizyki ciała stałego. Polskie Wydawnictwa Naukowe Warszawa.

39. Ren L, Zhu J, Nan L, Yang K (2011) Differential scanning calorymetry analysis on Cu precipitation in a high Cu austenitic stainless steel. Mater Des 32: 3980-3985.

40. Zhao YH, Liao XZ, Jin Z, Valiev RZ, Zhu YT (2004) Microstructures and mechanical properties of ultrafine grained $7075 \mathrm{Al}$ alloy processed by ECAP and evolutions during annealing. Acta Mater 52: 4589-4599.

41. Gao N, Starink MJ, Longdon TG (2009) Using differential scanning calorimetry as an analytical tool for ultrafine-grained metals processed by severe plastic deformation. Mater Technol 25: 687-698.

42. Kubina T, Dlouhy J, Kover M, Domankova M, Hodek J (2015) Preparation and thermal stability of ultra-fine and nano-grained commercially pure titanium wires using conform equipment. Mater Technol 49: 213-217. 